
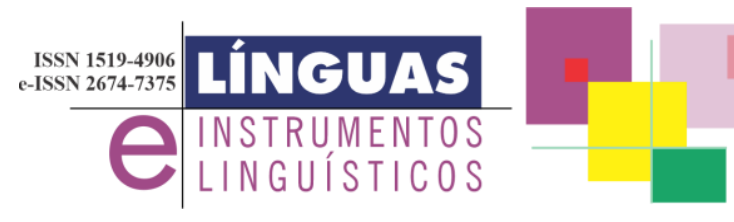

DOI: $10.20396 /$ lil.v24i48.8666487

\title{
Línguas indígenas, fronteiras e silenciamento
}

\author{
Indigenous languages, borders and silencing
}

\section{Tania Conceição Clemente de Souza* UFRJ}

\begin{abstract}
Resumo: O trabalho tem como objetivo discutir as consequências trazidas pela colonização no que se refere às constantes migrações de povos e línguas em trânsito entre diferentes fronteiras. No bojo dessa discussão trazemos à tona o conceito de línguas silenciadas, ao lado dos processos de retomadas e ressurgência das línguas originárias brasileiras, com foco em especial na situação linguística registrada em terras Baníwa. A partir da Análise de Discurso, adotamos como principais pressupostos a noção de hospitalidade (ORLANDI, 2012), a constituição da forma-sujeito e o conceito de identidade etnodiscursiva (SOUZA, 2020a).
\end{abstract}

Palavras-chave: Línguas silenciadas, Identidade etno-discursiva, migração, Retomada de línguas.

Abstract: Our paper takes as objective to discuss the consequences brought by the colonization process with regard to the constant migrations of peoples and languages in transit between different borders. Within this discussion, we bring up the concept of silenced languages, alongside the processes of retake and resurgence of original Brazilian languages, with a special focus on the linguistic situation registered in Baniwa lands. From Discourse Analysis we adopt as main assumptions the hospitality notion (ORLANDI, 2012), the constitution 
of the subject-form and the concept of ethno-discursive identity (SOUZA, 2020a).

Keywords: Silenced languages, Ethno-discursive identity, Migration, Language retake.

Esta língua não é minha, qualquer um percebe. Quando o sentido caminha, a palavra permanece. Leminski

Tomamos como objetivo primeiro deste trabalho discutir a situação linguística atestada entre os Baníwa, assentados em terras Baníwa, localizadas na fronteira do Brasil com a Colômbia e Venezuela, em aldeias localizadas às margens do Rio Içana e seus afluentes Cuiari, Aiairi e Cubate ${ }^{1}$. Os demais objetivos abrangem a discussão em torno do silenciamento massivo das línguas originárias brasileiras em contraponto com o movimento de retomada e ressurgência de muitas línguas até então consideradas extintas. As duas situações, tanto o silenciamento quanto as retomadas, decorrem das constantes migrações de povos e línguas por entre diferentes fronteiras. Também localizaremos historicamente como vem se instituindo a política de distribuição de terras indígenas, tendo como ponto de partida o século XIX.

\section{Colonização, Migração e Silenciamento}

Há muito tempo, discuto o silenciamento das línguas originárias do Brasil, definindo o conceito de línguas silenciadas ${ }^{2}$. Parto do princípio de que o "silêncio significa, não fala" (ORLANDI, 1992) e defendo que as línguas - tomadas como extintas ou mortas - significam pelo seu silenciamento (SOUZA, 1994, 2011, 2020a, 2021 (no prelo), entre outros):

A decisão de falar em línguas silenciadas não é por uma questão de eufemismo, mas sim por 
razões de ordem política e teórica. Silenciar é impedir que certos sentidos indesejáveis transitem no bojo do discurso social, definido como aquilo que é permitido dizer, como assinala Pêcheux (1975). Assim não podemos dizer x, dizemos y. As línguas se silenciam, mas são ouvidas na denominação dos povos indígenas - Puri, Tupinambá, Mura, Baré... Ecoam o tempo todo, toda vez que se repetem os nomes desses povos. Se as línguas se extinguem, extinguem-se os povos, os saberes, a cultura de todos que assim se nomeiam? $?^{3}$

A categoria de línguas mortas não estaria, a princípio, vinculada a nenhum falante que historicamente descenderia de um povo, cujos indivíduos não mais se declararem ligados a qualquer filiação étnica. Com relação à língua extinta, esta se definiria como não mais falada em tempos atuais, apesar de ainda existirem povos com filiação étnica declarada. Sãos estas últimas que defino como silenciadas, mas sempre possíveis de revivência, de revitalização. As línguas migram, transitam no tempo e no espaço. A migração das línguas se dá, por exemplo, no trabalho contínuo de gestos políticos de retomada, de ressurgência, recorrendo-se a sábios e lembradores. Nos gestos de cooficialização de diversas línguas, garantindo uma certificação jurídica. Esses gestos da ordem do político, da ordem do discurso - trabalham na contramão da extinção e investem no silenciamento como linha de fuga, enfim como resistência.

Quando falo de migração das línguas me refiro ao movimento das línguas que transitam entre fronteiras geográficas e políticas: hoje em dia, povos alocados no nordeste, ou norte do país adotam, por exemplo, o tupinambá como língua de ressurgência/retomada. O tupinambá era falado por populações litorâneas localizadas principalmente no sudeste do país. Quando passa a ser falado por um povo, cuja língua já se silenciou, caso dos Potiguar, na Paraíba, ou dos Tupinambá, adotado em Olivença, na Bahia, dentre outros, a língua tupinambá migra de território em território, rompe fronteiras e ressurge, embora tenha sido considerada extinta.

Os Tupinambá de Olivença são indígenas que reivindicam direito às terras imemoriais, onde antes habitavam os Tupinaki de Olivença, e 
outros povos, totalmente dizimados em função da usurpação de suas terras. Nimuendajú, em carta datada de 8 de dezembro de 1938 a Carlos Estêvão de Oliveira, já denunciava:

Aproveitei a demora em Ilhéos para fazer uma visita aos índios descendentes dos Tupinaki que habitam nas vizinhanças de Olivença. [...] Estes índios são amáveis e de fácil tratamento, mas os seus vizinhos neobrazileiros procuram por todos os meios, por vexames e ameaças fazer com que lhes 'vendam' as suas terras, e como elles não acham quem os defenda, o desmembramento do grupo é questão de pouco tempo ${ }^{4}$.

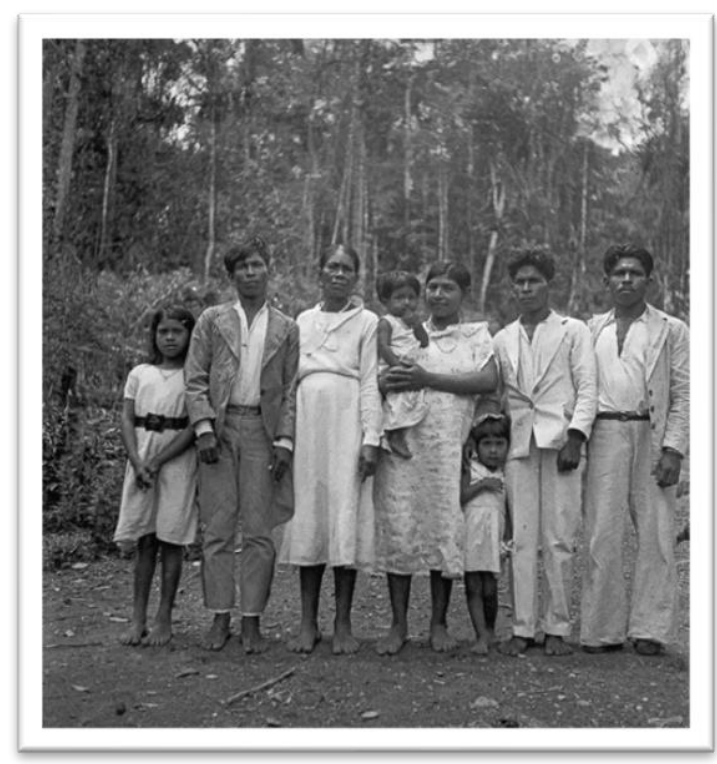

Família - Tupinaki de Olivença

Curt Nimuendajú - $1938^{5}$

A migração das línguas e a usurpação de terras, denunciadas por Nimuendajú, datam, porém, de longo tempo. À medida que o colonizador ia se assenhorando do território, os povos indígenas eram arrebatados para o trabalho escravo, para o extrativismo mineral e 
vegetal, para guerras, para acompanhar as grandes expedições e para tantas outras funções. Assim, com o século XIX, cresce o número de decretos e leis sobre os direitos de ocupação das terras e, gradativamente, os povos originários vão perdendo terreno.

Carneiro da Cunha (1992, p. 133) considera o século XIX como um século heterogêneo, é neste período (chegando ao começo do século $\mathrm{XX}$ ) em que se dá o "estreitamento da arena em que se discute e decide a política indigenista." Desde 1759, com a expulsão dos jesuítas por Pombal, não se tem mais um projeto, ou voz a favor de interesses indígenas. Os missionários que aqui chegam a partir da década de 1840 ficam totalmente "a serviço do Estado". Assim, a política que aí se desenvolve (com a emissão de várias leis e decretos) faz deslocar a requisição da mão de obra indígena para a questão da ocupação do território.

Debate-se a partir do fim do século XVIII e até meados do século XIX, se se devem exterminar os índios "bravos", "desinfestando" os sertões solução em geral propícia aos colonos — ou se cumpre civilizá-los e incluí-los na sociedade política - solução em geral propugnada por estadistas e que supunham sua possível incorporação como mão-de-obra. Ou seja, nos termos da época, se se deve usar de brandura ou de violência. Este debate, cujas consequências práticas não deixam dúvidas, trava-se freqüentemente de forma toda teórica, em termos da humanidade ou animalidade dos índios. (CARNEIRO DA CUNHA, 1992, p. 134).

Embora a autora situe sua discussão no século XIX, assinala que essa situação se estende ao começo do século XX. São muitos os registros de índios sendo dizimados por outros índios, caso, por exemplo, dos Puri ${ }^{6}$ de Minas Gerais, quando os Corados de Valença foram usados para este fim. (CARNEIRO DA CUNHA, idem). São vários os artifícios traçados em função da espoliação das terras e extermínio dos índios, com fins de "desinfestar os sertões" (idem), a começar pela criação das aldeias: os índios brabos ficam alojados em tribos, para os mansos são criadas as aldeias, regidas pelas leis dos 
colonizadores. Este sistema de aldeamento lograva, ao final, a usurpação das terras, estas cedidas aos índios mansos, mas desapropriadas a qualquer momento, quando então se cria o estatuto de terras devolutas. Por outro lado, as terras adequadas aos aldeamentos não correspondem às terras onde os índios originariamente as ocupavam. E, ainda, dentro de um mesmo território demarcado como aldeamento indígena, eram atribuídas aos colonos faixas de terra como possível arrendamento. Os rendimentos daí provenientes deveriam servir para o sustento dos índios e familiares. Com o passar do tempo e interesse pelo Estado $^{7}$ nessas terras, os índios são acusados de realocarem as suas terras para população não indígena. Razão suficientemente legal para transformar os aldeamentos em sesmarias, ou em lotes a serem arrendados e/ou aforados. Assim pouco a pouco, os aldeamentos ficavam cada mais reduzidos. Além desses, outros artifícios jurídicos contribuíam para "desinfestar os sertões". Se os índios aledados migravam para outras faixas de terras, como caçadores e coletores, deviam perder as terras, pois não tinham o senso de propriedade. Havia também a possibilidade de adoção de filhos dos indígenas, e a internação de crianças e jovens nas instituições religiosas. Acrescento, então, que jovens e crianças passam a ter certidões com nomes cristãos e, na maior parte das vezes, apagando-se o nome indígena. Trata-se, na verdade, de se afirmar um tipo de genocídio jurídico, e consequente apagamento da existência de população indígena. Uma vez não indígena, não há alienação aos direitos previstos em lei. Algumas províncias passam a declarar a total inexistência de índios na região. Ceará foi a primeira província a negar a existência de índios identificáveis nas aldeias e se apropriar das suas terras, em 21/10/1850 (CARNEIRO DA CUNHA, 1992, p. 145). Os atestados de óbito também são lavrados sem reconhecimento étnico.

Todas essas práticas são muito bem arroladas e discutidas em Carneiro da Cunha, situando toda a criação desses artifícios jurídicos (leis e decretos) no século XIX. Cada vez mais os índios aldeados vão sendo extintos, e aí se institui a disputa por essas terras. Pelo que se tem até aqui, diríamos que a situação dos indígenas, hoje em dia, não se diferencia muito no que se refere a uma política de Estado com relação à demarcação de terras e ao impedimento das constantes invasões de madeireiros, garimpeiros, posseiros. Confira-se a respeito a nova instrução normativa (9/2020) da FUNAI que desprotege as terras 
indígenas não homologadas. Com essa nova portaria, o governo autorizou o cadastro privado de mais de duas mil propriedades em terras indígenas, num total de 250 mil hectares, em áreas onde vivem até povos isolados. ${ }^{8}$ Claramente, ressoa hoje em dia, após 170 anos, os preceitos da Lei das Terras (Lei 601 de 18/09/1850) e de outras leis, referidos acima.

Além disso, em dias recentes, outros direitos são negados, como por exemplo, o programa de vacinação de Covid-19, que se estende apenas a índios aledados. Os índios em contexto urbano não são reconhecidos como índios; enquanto no século XIX, os índios eram tribais e aldeados, hoje joga-se com as categorias de aldeados e em contexto urbano (registrados no Censo IBGE 2010). Lida-se também com a categoria de índios autodeclarados, estes sem direito à homologação de terras, ainda que alocados em terras imemoriais, e atualmente com reconhecimento étnico restrito, dada a retificação do princípio de autodeclaração: em janeiro do corrente ano, a FUNAI, através de norma complementar (28/01/2020), afirma não ser mais suficiente apenas a autodeclaração étnica para reconhecimento jurídico identitário. Foram retomados antigos critérios ${ }^{9}$ - "técnicos científicos, e cujas características culturais sejam distintas na sociedade não índia" - para o reconhecimento, tais como a prática de expressões culturais tradicionais e, sobretudo, o domínio da língua indígena.

Sobre a relação do sujeito com o Estado, podemos destacar um fato essencial: o poder, o Estado e o direito coagem o sujeito, insinuam-se nele de forma discreta. Daí resultam claros processos que derivam de uma técnica particular de poder que Foucault (1984) designa como sendo um governo pela individualização, uma forma de poder que classifica os indivíduos em categorias, identifica-os, amarra-os em sua identidade. Trata-se de um mecanismo coercitivo de individualização, de isolamento, o que leva a pensar que o Estado, sem dúvida, induz os indivíduos a "uma lei de verdade que devem reconhecer e que outros devem reconhecer neles. É uma forma de poder que transforma indivíduos em sujeitos"10 (idem, p. 302). E institui um sistema de diferenciações que permite atuar sobre a ação de outrem: diferenças jurídicas ou tradicionais de status e privilégios; diferenças econômicas na apropriação de riquezas e bens; diferenças existentes nos processos de produção; diferenças linguísticas ou culturais; diferenças de saberfazer e competências, etc. Qualquer relação de poder põe em jogo 
diferenciações que são, assim, simultaneamente condições e efeitos (FOUCAULT, 1984, passim).

Mas, apesar do sistema e da categorização pelo Estado, há formas de resistência, de lutas. Ainda em Foucault, há três tipos de luta:

Em termos gerais, podemos dizer que existem três tipos de lutas: as que se opõem a formas de dominação (étnica, social e religiosa); as que denunciam formas de exploração que separam o indivíduo daquilo que ele ou ela produz; e as que combatem tudo aquilo que liga o indivíduo a si próprio e assim assegura a sua submissão aos outros (lutas contra a subjugação, contra as várias formas de subjetividade e submissão). (FOUCAULT, 1984, p. 303) ${ }^{11}$

E é no bojo dessas considerações, que se assinala a importância da retomada de uma língua outra, diferente da língua de origem, ou a importância da ressurgência de povos originários e de línguas silenciadas, que se definem pelos três tipos de luta acima. $\mathrm{O}$ que nos leva a discutir a noção de identidade étnica e propor a noção de identidade discursiva, gesto claro de subjetivação. No movimento de todas as práticas discursivas, ou lutas, sublinhadas até então, pode-se ainda perceber a constituição histórica da forma-sujeito-índio, pensada por nós não como a forma-sujeito única do capitalismo, mas, "ainda assim com base em Pêcheux (1975, p. 163), quando afirma que "a interpelação do indivíduo em sujeito de seu discurso se efetua pela identificação (do sujeito) com a formação discursiva que o domina, isto é, na qual ele ocupa, aí se reconhece como sujeito e diz": sou índio (SOUZA, 1994)".

\section{Decolonização e Identidade Discursiva}

Pelas anotações de cronistas e viajantes, nos deparamos com a necessidade de os indígenas se engajarem, já no século XVIII, no trabalho externo - extrativismo e pecuária -, além dos aldeamentos impostos pelo colonizador. Instaura-se, assim, uma dispersão entre os povos indígenas, resultando, como se deduz, no silenciamento de muitas línguas. Em termos atuais de situação linguística, tem-se, por 
um lado, o silenciamento de um contingente grande de línguas indígenas e, por outro, a retomada de línguas indígenas, como o exemplo do nheengatu (com 20000 falantes, pelo Censo 2010), ou a ressurgência de línguas consideradas extintas.

O silenciamento das línguas, ou a total extinção de centenas de povos indígenas, não se dá apenas pela dispersão. No século XVI, como assinala Rodrigues $(2005)^{12}$, estima-se que seriam faladas em torno de 1200 línguas em território brasileiro, hoje é estimado um total aproximado de 170 línguas, tendo em conta as variações dialetais de uma mesma língua. Um outro fato que chama atenção está na inconsistência dos relatos de viajantes quanto à nomeação genérica de povos e línguas, tais como Coroados, Botocudos, Tapuias. São determinações que se efetuam por perífrases: aqueles que usam coroas de penas, aqueles que usam botoques nos lábios, aqueles que são inimigos dos Tupi.

Sobre esse funcionamento do nome próprio, nos remetemos a Pêcheux (1975), a partir de sua reflexão em contraponto ao que propôs Frege. $\mathrm{O}$ "ponto decisivo, essa designação pelo nome próprio implica, correlativamente, a possibilidade de designar "a mesma coisa" por uma perífrase, tal como "aquele que descobriu ", "a cidade que é a capital da Alemanha", etc.". O que significa dizer que aos nomes próprios "simples" correspondem necessariamente nomes próprios "compostos", não lexicalizados, mas sim construídos por diversos funcionamentos sintáticos, [...] dentre os quais "aquele que..." (PÊCHEUX, 1975, p. 100). A indeterminação inscrita em "aquele que...", ainda em Pêcheux, se encontra tanto no discurso do aparelho jurídico, quanto no funcionamento do 'cotidiano'.

Se se indeterminam os nomes com perífrases generalizantes, também se indeterminam os nomes das línguas, como é o caso da língua dos Coroado. Que línguas seriam faladas sob essa alcunha? O trabalho que tem sido feito no campo da Linguística Histórica é recorrer às listas de palavras coletadas em diferentes épocas e por diferentes viajantes, efetuando a comparação de cognatos e chegando-se a alguma conclusão sobre a que parentesco linguístico se agregaria, por exemplo, a língua coroado. Embora esse tipo de material seja, na maioria das vezes, esparso e difuso, os linguistas têm, em muitos casos, chegado a uma sistematização a partir deles. Como é o caso dos Puri, cuja língua e o povo são anotados como extintos, e que, hoje em dia, encabeçam um 
movimento de ressurgência do povo e da língua. Rodrigues (1998) chega à conclusão de haver uma família linguística Puri, filiada ao tronco macro-jê, composta pela língua puri, coroado e coropó. As semelhanças entre puri e coroado são tantas que, na maioria das vezes, se escreve puri-coroado, ou puri (coroado), admitindo-se ser uma só língua com quase nenhuma diferença e, possivelmente, seria também o mesmo povo. Ainda em Rodrigues, o puri é classificado como língua morta, e os Puri também estariam extintos.

Os Puri, pelo que se tem historicizado, caíram na armadilha de arrendamentos das suas terras a fazendeiros. Terras que acabaram sendo escrituradas no nome desses "novos" donos que arrebataram os Puri para o trabalho escravo, ou até mesmo assalariado ${ }^{13}$. Com relação à língua puri, esta não consta da lista das línguas faladas hoje em dia e quanto ao povo, Carneiro da Cunha, como assinalamos acima, diz terem sido os Puri dizimados pelos Coroados. Entretanto, descendentes dos Puri vêm comprovando sua filiação e buscando se legitimar como tal com autodeclarações. Estes estão também engajados no movimento de ressurgência do povo e da língua puri, se valendo desses antigos relatos e da recorrência a alguns velhos lembradores.

Quanto à identidade indígena, esta em geral é discutida pelo viés étnico, quando se constata a preservação de manifestações culturais, de organização social, de relações de parentesco, de herança de espólio matrilinear ou patrilinear e da própria denominação étnica. Levando em conta toda a situação das línguas indígenas instaurada pelo confronto trazido pela colonização, podemos pensar, em termos discursivos, numa constituição da identidade indígena por outro viés, que não seja estritamente o étnico, mas sim pela(s) língua(s). Um dos critérios oficiais do Estado para reconhecimento dos povos indígenas - e aí reafirmar os direitos destes previstos na Constituição brasileira - é o domínio da língua indígena. Por esse critério, muitos desses povos originários correm o risco de ficarem alijados das políticas indigenistas e de seus direitos. A retomada da língua indígena (seja qual for) vem, assim, em confronto com tal critério, 
num movimento político de reafirmação da identidade indígena em termos linguísticos e discursivos, e não apenas pela etnia. (SOUZA, 2020a).

Tomo como exemplo recente do que defino como identidade discursiva, a forma como um candidato ${ }^{14}$ ao Mestrado Profissional em Linguística e Línguas Indígenas (Museu Nacional) abre seu memorial: "Sou Baré e minha língua materna é o nheengatu". Há tempos que a língua baré foi silenciada, no entanto, dentro do movimento de reafirmação da identidade indígena, o nheengatu - língua falada por 20000 indivíduos - vem sendo retomado como língua materna por diversos povos de diferentes etnias. O nheengatu, língua cooficializada em 2002, também é falada por não indígenas, e tem um alcance maior de comunicação na região do Alto Rio Negro do que o português.

Em Souza (2021 (inédito), estendo os conceitos de falante e usuário, propostos por Orlandi (2012), ao trabalho de ressurgência e retomadas de línguas indígenas. Para a autora:

Se antes devíamos abandonar o falar local, a língua materna, pela noção de unidade, nacional, hoje nos fragmentamos em falares locais, dificilmente visíveis, pouco conhecidos (não gramatizados), enquanto do outro lado, paralelamente, flui livremente, sustentado por uma enorme quantidade de instrumentos linguísticos, e com toda a visibilidade e apoio tecnológico, a língua franca "universal" da comunicação e do conhecimento: a língua única (nas condições atuais, o inglês). Língua dominante não só no espaço digital, o espaço da multidão de usuários (ORLANDI, 2012, p.15).

No âmbito do que nos interessa aqui, estendo a distinção entre falante e usuário ao universo das línguas indígenas. Já apontamos que uma das causas para o silenciamento das línguas indígenas está, desde o século XVIII com Pombal, na imposição do português - língua de dominação - como língua franca e de comunicação no dia a dia em nosso território. Há historicamente, enfrentamentos, confronto entre 
povos e o colonizador, e não de contato, afirmação que sedimenta nossa reflexão pela ordem do discurso, e não no campo da afetação entre línguas. E, nesse sentido, é clara a polissemia do sentido de língua materna em: "Sou Baré e minha língua materna é nheengatu".

Nesse breve enunciado ecoa, a nosso ver, todo o histórico de espoliação dos índios a que já nos referimos aqui. Há muito que o baré é uma língua silenciada, mas o sujeito se reconhece indígena por dois movimentos: pela reafirmação de sua etnia - Baré - e pelo reconhecimento de sua identidade discursiva: a língua materna é o nheengatu (SOUZA, 2020a e 2021 (inédito)). Nessa forma de subjetivação num território em que "o sujeito se sente em casa" (DELEUZE E GUATARRI, 1995), não há espaço para o português. Vem à tona sua filiação linguística étnica - Baré - e sua identidade de língua materna - o nheengatu - e apaga, neste enunciado, falar português. Processo complexo e paradoxal: fala e escreve em português como usuário dessa língua outra, mas nomeia sua posição discursiva: sou índio Baré, falo nheengatu.

Assim, dentro de um processo claro de resistência, os povos indígenas são usuários do português - e não falantes - e passamos a entender o português como língua franca. A ressurgência de povos e línguas nada mais é que um gesto pleno de decolonização e que, ao mesmo tempo, denuncia o desrespeito imposto aos povos originários.

\section{Fronteiras, Hospitalidade e Baníwa}

O conceito de fronteira que adotamos não se atém a fronteiras geográficas, demarcação de territórios, mas se relaciona ao modo de vida e aos limites socialmente definidos. Cada grupo, ou sociedade, trabalha sua relação com espaço de forma diferenciada (COSTA, 1991). Ou seja, pensamos como, dentro de uma mesma organização social, se institui, muitas vezes, uma diáspora com relação ao trabalho, aos modos de produção e à atitude (sentido laboviano) ${ }^{15}$ frente à língua.

Com certeza em qualquer sociedade, a definição acima se aplicaria, mas vamos nos deter num caso em particular: a sociedade Baníwa. A história do povo Baníwa não é diferente da história de outros povos. Alguns autores, até agora, em estudos de antropólogos, linguistas e outros pesquisadores usam o nome Baníwa-Curipaco, mas um linguista Baníwa (MELGUEIRO-BANÍWA, 2008) afirma que são dois povos 
diferentes, diretriz que seguiremos em nosso percurso. Os Baníwa que vivem na região do Ato Rio Negro perfazem uma população de 5768 indivíduos, segundo o Censo IBGE 2010. A língua baníwa pertence à família Aruák, mas nem todos os Baníwa falam a língua de origem. "A partir do médio Içana para o norte, os Baníwa e Curipáco falam suas línguas tradicionais e de Assunção (missão Salesiana fundada em 1955) para baixo falam a Língua Geral ou Nheengatu, introduzida pelos salesianos" (MELGUEIRO-BANÍWA 2008, p. 24). O nheengatu é uma língua forjada pelos jesuítas e de base tupi. Em termos da situação linguística entre os Baníwa, o que se tem num mesmo território é a fluência de três línguas: baníwa, nheengatu e português, este como meio de comunicação entre os dois grupos Baníwa. Uma situação complexa, que não se encaixaria estritamente numa relação de diglossia, uma vez que não se pode falar de uma língua dominante face a outra. São duas atitudes diferentes entre esses dois grupos de falantes pertencentes à mesma organização social. E o português funcionando como meio de comunicação entre ambos. Assim, nas terras Baníwa temos falantes de nheengatu, falantes de baníwa e usuários do português.

Rosário Baníwa, em entrevista em abril de $2019^{16}$, nos conta que na época da extração da borracha boa parte dos Baníwa saiu para se engajar nessa frente de trabalho, tanto assim que a "mãe nasceu no Rio Branco, do Acre. Minha mãe foi professora rural e participou de vários movimentos indígenas em defesa dos nossos direitos e nunca aprendeu Baníwa, nem eu, nem meus irmãos, nem meu pai.” Indagada se essa situação era restrita à sua família, Rosário respondeu:

O que aconteceu, é que, no tempo da colonização, quando a Sofia ${ }^{17}$ entrou, a maioria do pessoal de baixo, eles perderam a língua, que no caso é o baníwa. Aí de Assunção pra lá eles permaneceram com o baníwa fluente, por causa dessa entrada dos missionários evangélicos. Então, o pessoal de baixo fala nheengatu, e os de Assunção falam baníwa.

Retomando o que colocamos acima - "a perda da língua” - com relação à instauração de limites sociais, tem-se uma fronteira decorrente de um modo de produção estranho à cultura original do povo, como a extração da borracha e decorrente também de atitudes frente à língua. 
Todos se conhecem e se reconhecem como Baníwas, mas são falantes de línguas diferentes, estas com filiações linguísticas estranhas entre si (aruak e tupi). Em jogo estão aí a questão da identidade etno-discursiva e a relação com o espaço/território diferenciada, uma parte dos Baníwa se manteve em terras originais, enquanto a outra parte se desterritorializa num determinado curso do tempo, para depois se reterritorializar num espaço imemorial.

A relação dos sujeitos com o espaço discutida em Orlandi (2014) aponta para a formulação de princípios pertinentes à nossa reflexão, como o conceito de hospitalidade entre as línguas (2012 e 2014), que vamos explorar para entender melhor a situação linguística entre os Baníwa.

Para Orlandi, falar em espaço significa projetar esta noção, para além do campo da Linguística, e se remeter à globalização, "pensada em sua forma política que é a de apagar, pelo menos imaginariamente, os limites histórico-políticos e socioculturais, próprios da relação Estado/Nação vigentes.” (ORLANDI, 2014, p. 20). Propõe, então, pensar as muitas línguas brasileiras "de modo pluricêntrico", deslocando, por sua vez as concepções de plurilinguismo e de multilinguismo, e falar em polilinguismo, contraponto a multiculturalismo e plurilinguismo. Segundo a autora as relações entre as línguas são polissêmicas; são relações que jogam com a transferência, o movimento, a deriva. $\mathrm{O}$ polilinguismo está na própria possibilidade de transformação das línguas. A partir daí Orlandi repensa a ideologia da globalização como processo dinâmico a aberto.

Por que polinguismo? Para levar em conta, por um lado, a polissemia entre as línguas, e, dentro do universalismo histórico ${ }^{18}$, unir "diferentes línguas em seus campos de relações e praticá-las de forma a estabelecermos relações entre seus sujeitos falantes, objetivando, assim, desfazer o monolinguismo com seus usuários" (idem). Ao visar a possibilidade de uma humanidade compartilhada, Orlandi (2012), explora a noção de contato entre línguas que aceite a hospitalidade:

Pois bem, retomando o Ulisses da Odisséia, podemos nos perguntar: "Qual é o povo ao qual cheguei desta vez? São ladrões inumanos ou partidários do sagrado direito da hospitalidade?". Segundo Dauk (2006), Ulisses estabelece pela 
primeira vez os limites do mundo dos humanos e o critério do traçado deste limite é a hospitalidade. Esta ideia relaciona os humanos (eu diria os sujeitos) entre si por sobre as fronteiras étnicas e culturais. Mas o "estranho" nunca deixou de ser uma figura ambígua e a questão das fronteiras (espaços?) sempre se colocou (ORLANDI, 2012, p. 8).

Com base no conjunto dos argumentos de Orlandi (idem), retomo a situação dos Baníwa, para verificar que as "fronteiras" que se estabeleceram entre os sujeitos Baníwa diz respeito, por um lado, à identificação com línguas estranhas entre si no âmbito da filiação linguística originária, mas que, por afinidade e por reconhecimento étnico, trabalham a fluência de três línguas a partir "dos limites do mundo dos humanos e o critério do traçado desses limites é a hospitalidade". Para os Baníwa, a divisão entre as línguas existe e se mantém, porém as fronteiras étnicas e culturais se deslocam. Afinal, a língua estranha - "a figura ambígua" - entre eles não é o baníwa, nem o nheengatu, língua materna por adoção. A língua de dominação não lhes pertence, como diz o poeta da nossa epígrafe. Os Baníwa não se rendem a ela, ao contrário, se confrontam com o português por contingência, não por adoção. Retorno, então, ao conceito de identidade discursiva que se constitui na e pela(s) línguas. Que se constitui não por se falar o mesmo idioma e, menos ainda, por se falar uma língua outra, do outro, sempre estranho.

\section{Conclusão}

A exploração dos povos indígenas, datada de cinco séculos, resultou em grandes genocídios, da ordem do humano e do jurídico. Afinal, para o Estado, era preciso - e é até hoje - desinfestar os sertões! Resultou, também, na extinção e silenciamento de muitas línguas originárias. Com a imposição do português - essa língua que não é minha -, os povos não só calam as suas línguas, como calam também a identidade: os Baré, por exemplo, por muito tempo não se reconheciam como indígenas. Tal situação, entretanto, vem mudando. Acima, em Carneiro da Cunha, vimos que com a saída dos jesuítas, os índios ficam sem 
nenhuma voz a seu favor. Hoje, são muitos os movimentos indígenas em luta contra as formas de dominação (étnica, social e religiosa); contra as formas de exploração que separam o indivíduo daquilo que produz; contra a subjugação e contra as várias formas de subjetividade e submissão. Uma dessas lutas é, sobretudo, pelas retomadas e ressurgências da língua.

"Essa língua não é minha, qualquer um percebe". Esses versos do poeta Leminski, com certeza, ilustram a historicidade que perpassa as línguas brasileiras e, ainda, recobre os movimentos de hoje desses povos originários. As línguas migram, mudam de lugar, mas a formasujeito índio permanece, apesar das fronteiras fragmentadas e violadas. Esta forma-sujeito se reconfigura em movimentos contínuos de subjetivação e, enfim, busca se proteger da figura ambígua que é o estranho. Gestos instituídos na articulação do político e do simbólico.

\section{Referências}

CARNEIRO DA CUNHA, M. "Política indigenista no século XIX". In: CARNEIRO DA CUNHA, M. (org). História dos Índios no Brasil. São Paulo: Companhia das Letras. p.133-154, 1992.

COSTA, W. M. O Estado e as políticas territoriais no Brasil. São Paulo: Contexto, 1991.

DELEUZE, G.; GUATARRI, F. (1995) Mil platôs - capitalismo e esquizofrenia. Tradução de Ana Lúcia de Oliveira e Lúcia Cláudia Leão. Rio de Janeiro: Ed. 34, 1995.

FOUCAULT, M. "Deux essais sur le sujet et le pouvoir: pourquoi étudier le povoir: la question du sujet". In: DREYFUS, H. ; RABINOW, P. (orgs) Michel Foucault, un parcours philosopfique (su-delá de l'objectivité et de la subjectivité). Paris: Gallimard. 297321, 1984.

GRUPIONI, L. D. B. Coleções vigiadas: os etnólogos no Conselho de Fiscalização das expedições artísticas no Brasil. São Paulo: Hucitec, 1998.

LABOV, W. Sociolinguistics patterns. Philadelphia: University of Pensylvania Press, 1972.

LEMOS, M. M. O índio virou pó de café? Resistência indígena frente à expansão cafeeira no Vale do Paraíba. Jundiaí, SP: Paco Editorial, 2016. 
MELGUEIRO-BANÍWA, E. M. Sobre a natureza, expressão formal e escopo da classificação linguística nas entidades na concepção do mundo dos Baníwa. Dissertação de Mestrado. Universidade de Brasília, 2008.

ORLANDI, E. P. As Formas do Silêncio. Campinas: Editora UNICAMP. 1992.

ORLANDI, E. P. "Espaços Linguísticos e seus desafios: convergências e divergências". In: RUA, n.18, vol.2, 2012.

ORLANDI, E. P. Ciência da linguagem e Política: Anotações ao Pé das Letras. Campinas, SP: Editora Pontes, 2014.

PÊCHEUX, M. Semântica e Discurso. Campinas, SP: Pontes. 1975.

RODRIGUES, A. D. Línguas brasileiras. Para o conhecimento das línguas indígenas. São Paulo: Edições Loyola, 1986.

RODRIGUES, A. D. "As vogais orais do Proto-Tupi". In: RODRIGUES, A.D.; CABRAL, A.S.A.C. (Orgs.). Novos estudos sobre línguas indígenas. Brasília: Editora da UnB, p. 35-46, 2005.

SOUZA, T.C.C. de. (1994) Discurso e Oralidade - Um estudo em língua indígena. Tese de Doutorado. UNICAMP, 1994.

SOUZA, T.C.C. de. "Língua nacional e materialidade discursiva: A influência do tupi." In: MELLO, H. et. all (orgs). Os contatos linguísticos no Brasil. Belo Horizonte: Ed. UFMG, p. 241-254, 2011. SOUZA, T.C.C. de. "Política linguística, política de línguas indígenas e identidade discursiva". Conferência de abertura no GT de Línguas Indígenas. Londrina, Paraná: XXXV ENANPOLL, 2020a.

SOUZA, T.C.C. de. "Histórias cruzadas: dizer o feminino, ouvir a mulher indígena". In: Daróz, E. P. et all. Tramas, linhas e bordados: o feminino em discurso. Vol. 1. Campinas, SP: Pontes, p. 93-122, 2020b.

SOUZA, T.C.C. de. "Política linguística, política de línguas indígenas e línguas silenciadas". In: Estudos Linguísticos nas Línguas Minoritarizadas (no prelo), 2021.

VIVEIROS DE CASTRO, E. Cartas do Sertão - de Curt Nimuendajú para Carlos Estêvão de Oliveira. São Paulo: Assírio \& Alvim, 2000.

Notas 
* Doutora em Linguística pela Unicamp. Professora Associada do Departamento de Antropologia do Museu Nacional/UFRJ. Docente da Pós-graduação em Linguística da Faculdade de Letras da Universidade Federal do Rio de Janeiro (UFRJ). Coordenadora do LABEDIS/MN/UFRJ.

${ }^{1}$ Cf.: https://pib.socioambiental.org/pt/Povo:Baniwa, acesso em 12/07/2021; acesso às 20:00.

${ }^{2}$ Faço um parêntese para sublinhar que falar em línguas silenciadas não é uma questão de relativização do olhar, mas sim de se apoiar numa sustentação teórica que trabalha no bojo do materialismo histórico. Logo, não se trata de um "objeto visto de várias perspectivas, mas de uma multiplicidade de objetos diferentes" (Paul Veyne). Por isso, são línguas silenciadas, mas línguas em potencial no lastro da sua historicidade. (Souza, 2020a).

${ }^{3}$ As línguas se silenciam, mas ressoam na memória de todos aqueles que um dia tiveram contato com a sua materialidade física. Que lembram de serem embalados com a língua da qual, certamente, reconhecem a sonoridade, o ritmo, inscritos no nome de alguma planta, de um artefato qualquer, e até no nome próprio. São línguas que não precisam de um significado imanente, basta a sua significância. (Souza 2020a e 2021 (inédito))

${ }^{4}$ Grupioni atesta que 4 cartas escritas por Nimuendajú entre junho de 1937 e março de 1940, endereçadas a Carlos Estevão de Oliveira, estariam guardadas no Museu Nacional, atualmente destruídas pelo incêndio em setembro de 2018. Trechos dessas cartas foram anotados por Grupioni (1998, p. 189-198). No livro (VIVEIROS DE CASTRO, 2000), em que foram reunidas as cartas de Nimuendajú a Calos Estêvão há a lacuna em termos cronológicos dessas 4 cartas.

5 Acervo pessoal. Em 2014-15 com recursos do Edital APQ4 FAPERJ e Edital UNIVERSAL CNPq, e em parceria com a FUNARTE, desenvolvi um projeto de restauração de 487 negativos (maioria em vidro e os demais em diacetato), que integravam o espólio de Nimuendajú, adquirido pelo Museu Nacional em 1958. A partir daí, por lei, cabe a mim o direito de posse dessas imagens. Em 2018 todo o acervo Nimuendajú se perdeu, exceto os negativos digitalizados e as fotos restauradas.

${ }^{6}$ Os descendentes de índios Puri vivem hoje em contexto urbano, localizados nos estados do Rio de Janeiro, Espirito Santo, Minas Gerais e São Paulo. Fazem parte de um movimento de ressurgência do povo e da língua Puri.

${ }^{7}$ Carneiro da Cunha se refere ao Estado, já no século XIX, sem discutir a criação de um Estado Nacional à época.

8 Cf: ESPECIAL: AMAZÔNIA SEM LEI; Bruno Fonseca, Rafael Oliveira. https://apublica.org/. Acesso em 19/10/2020, 15:43

${ }^{9}$ Critérios instituídos no regime ditatorial do país nos anos de 1964 a 1984.

${ }^{10}$ Tradução nossa: « une loi de vérité qu'il leur faut reconnaître et que les autres doivent reconnaitre en eux. C'est une forme de .pouvoir qui transforme les individus en sujets ». 11 Tradução nossa: « D'une manière générale, on peut dire qu'il y a trois types de luttes : celles qui s'opposent aux formes de domination (ethniques, sociales et religieuses); celles qui dénoncent les formes d'exploitation qui séparent I'individu de ce qu'il produit; 
et celles qui combattent tout ce qui lie I'individu à luimême et assure ainsi sa soumission aux autres (luttes contre I'assujettissement, contre les diverses formes de subjectivité et de soumission).».

12 Rodrigues (1994) assinalava um total em torno de 340 línguas, à medida que os estudos históricos se avolumaram, Rodrigues (2005) refaz essa estimativa para 1200 línguas.

${ }^{13}$ Confira-se a esse respeito Lemos (2016): O índio virou Pó de Café?, com excelente histórico sobre os Coroados do norte fluminense e sua total extinção. Lemos também faz parte do movimento de ressurgência dos Puri, estes, hoje, residindo em contexto urbano (cf: nota 6).

14 Trata-se do aluno Emerson Chaves de Oliveira, que me autorizou a divulgar seu nome.

15 Para Labov (1972), as atitudes linguísticas são reforçadas pelos atos de identidade de um indivíduo no seu grupo.

${ }^{16}$ Entrevista realizada em 04 de abril de 2019 com quatro mulheres indígenas - Cristina Luciano de Oliveira Canuto Baré, Eronildes de Souza Fermin Omagua, Maria Ângela Matos Moura Tukano e Maria do Rosário Piloto Martins Baníwa - com depoimentos sobre o feminino em sociedade indígena. A fala de Rosário teve duração de 20 minutos. A análise da entrevista como um todo está em Souza (2020b).

17 Sophia Müller, missionária americana que chega ao Brasil por volta de 1949, por mais de 40 anos serviu no ministério ao Senhor Jesus na Amazônia Brasileira, evangelizando duas tribos: Curipáco e Baníwa.

${ }^{18}$ Noção pensada por Orlandi (2014, p. 22) como o fato de ser possível reconhecer "no outro homem o que somos, admitindo as diferenças, sendo diferentes". 